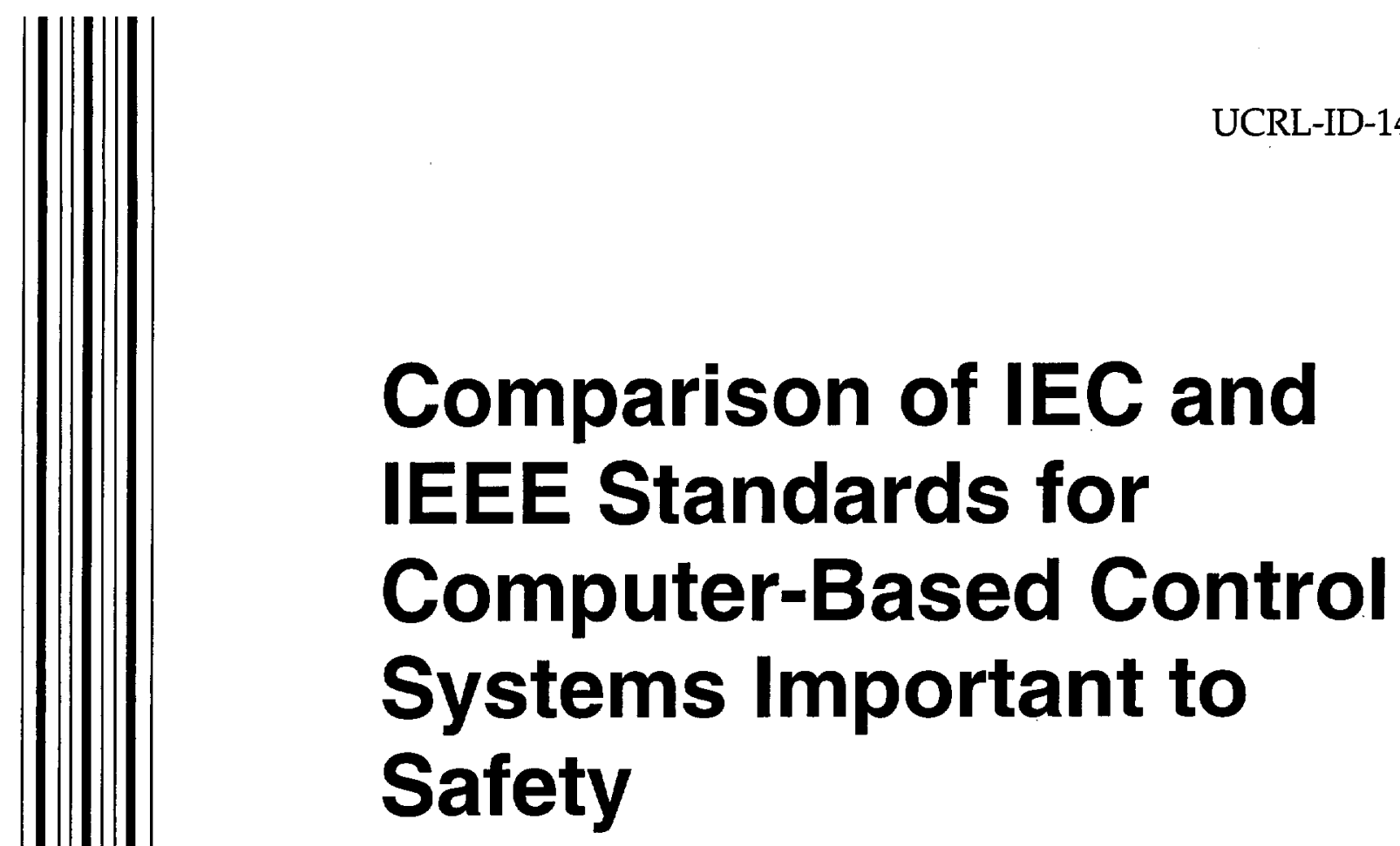

G. Johnson

December 19, 2001

U.S. Department of Energy

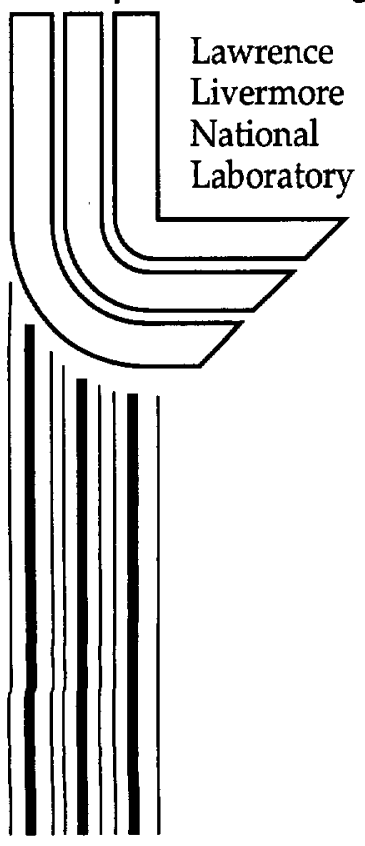




\section{DISCLAIMER}

This document was prepared as an account of work sponsored by an agency of the United States Government. Neither the United States Government nor the University of California nor any of their employees, makes any warranty, express or implied, or assumes any legal liability or responsibility for the accuracy, completeness, or usefulness of any information, apparatus, product, or process disclosed, or represents that its use would not infringe privately owned rights. Reference herein to any specific commercial product, process, or service by trade name, trademark, manufacturer, or otherwise, does not necessarily constitute or imply its endorsement, recommendation, or favoring by the United States Government or the University of California. The views and opinions of authors expressed herein do not necessarily state or reflect those of the United States Government or the University of California, and shall not be used for advertising or product endorsement purposes.

This is a preprint of a paper intended for publication in a journal or proceedings. Since changes may be made before publication, this preprint is made available with the understanding that it will not be cited or reproduced without the permission of the author.

This report has been reproduced directly from the best available copy.

Available electronically at http://www.doe.gov/bridge

Available for a processing fee to U.S. Department of Energy

and its contractors in paper from

U.S. Department of Energy

Office of Scientific and Technical Information

P.O. Box 62

Oak Ridge, TN 37831-0062

Telephone: (865) 576-8401

Facsimile: (865) 576-5728

E-mail: reports@adonis.osti.gov

Available for the sale to the public from

U.S. Department of Commerce

National Technical Information Service

5285 Port Royal Road

Springfield, VA 22161

Telephone: (800) 553-6847

Facsimile: (703) 605-6900

E-mail: orders@ntis.fedworld.gov

Online ordering: http://www.ntis.gov/ordering.htm

\section{OR}

Lawrence Livermore National Laboratory

Technical Information Department's Digital Library

http://www.llnl.gov/tid/Library.html 


\title{
Comparison of IEC and IEEE Standards for Computer-Based Control Systems Important to Safety
}

\author{
Gary Johnson ${ }^{1}$
}

\begin{abstract}
Summary
Many organizations worldwide develop standards that affect nuclear instrumentation and control $(I \& C)$. Two of the primary standards organizations are the US IEEE's Nuclear Power Engineering Committee (NPEC), and the IEC subcommittee on Reactor Instrumentation (SC45A). Today, nuclear power is very much an international industry. In this environment is vital that the activities of these standards organizations be in harmony.

This paper surveys the contents of the two sets of standards. Opportunities to improve consistency between the two sets are identified. It is hoped that this paper will excite a discussion of what might practically be done to improve the harmony between IEEE and IEC nuclear power standards.
\end{abstract}

\section{Introduction}

The collections of IEEE and IEC standards have some overlap, but in many cases cover significantly different topics. For example, IEEE standards go to great depth on environmental qualification of many specific types of components, while IEC covers the topic only at the general level. Conversely, certain IEC standards deal with specific instrumentation and control functions, a topic area where IEEE standards are largely mute. This paper studies two questions related to the above observations. Which standards in each body should be coordinated with each other? What opportunities exist for the two bodies to build on each other's standards to efficiently improve upon the coverage of their sets of standards?

Poor coordination between the two sets of standards poses a problem for the developers of systems for plant upgrades. Developers must try to address both sets of standards to avail themselves of a sufficiently broad market. Additionally, the IEEE and IEC standards together form a more comprehensive set of guidance than either set alone. If the interfaces between the standard sets were smoother, plant staff and system designers would have a better set of tools to help in the design and specification of I\&C upgrades.

To understand the similarities and differences between IEC and IEEE nuclear power standards layer diagrams were developed for each set of standards.

\footnotetext{
'Lawrence Livermore National Laboraton, P.O. Box 808, L-632, Livermore, CA, USA 94550. Tel: +1-925423-8834, Fax: +1-925-422-99J3, e-mail: johnson27@llnl.gov
} 


\section{Layer Diagrams}

Layer diagrams show the structure of a set of documents from the most general to the most specific. This study used the layer structure defined by Moore for the analysis of software engineering standards [Moore, 1998]. This structure uses six layers:

- Terminology - Documents prescribing terms and vocabulary.

- Overall guidance - Documents providing guidance covering the entire collection of standards.

- Principles - Documents describing principles / objectives for use of the standards in the collection.

- Element standards - Standards that are typically the basis for compliance.

- Application guides - Documents that supplement or give advice for using standards.

- Techniques - Documents describing methods and techniques that may be helpful in accomplishing requirements or guidance of the collection of standards.

Layer diagrams were developed for both the IEEE and IEC standards. The development of layer diagrams showed that the standards from both sets of organizations may be categorized into three groups: 1) standards describing general design topics that are applicable to all, or a wide range of specific functions, 2) standards dealing with human factors engineering issues including humanmachine interface design as well as human factors engineering techniques, and 3) standards dealing with specific instrumentation, control, or electrical system functions.

The combined layer diagrams developed to show the standards in each of these three categories are in Tables 1 through 4 . These diagrams represent one view of the standards. Other organizations are possible, but the organization selected here is at least useful to frame the discussion below.

\section{Analysis}

The needs for coordination may be understood by working down through the layers. The top three layers of each category are common to all diagrams. Each layer will be discussed generically. The other layers will be discussed for each category of standards. Before these are discussed there are some general comments.

The IEEE nuclear power standard set includes several genera! industry standards that were selected by NPEC as particularly relevant to the nuclear industry. There is no similar practice in IEC SC45A to embrace other committees' standards. The IEEE list of relevant general standards has not been updated recently. Certain software engineering and EMI standards endorsed by NRC might be added.

The IEC standards are considered industry specific standards under a general industry systems standard, IEC 61508. This is a relatively new development and the relationship between 61508 and the nuclear standards has not yet matured. No comparable relationship exists in the IEEE sphere.

The IEC depends upon IAEA safety guides to provide overall design principles for $1 \& \mathrm{C}$ systems, therefore, this analysis treats the overarching IAEA I\&C safety guides as IEC principle standards. Currently these principles are provided in IAEA Safety Guides D3, "Protection System and Related Features in Nuclear Power Plants," and D8, "Safety Related Instrumentation and Control Systems in Nuclear Power Plants." These two guides are soon to be replaced by a unified guide, "Instrumentation and Control Systems Important to Safety in Nuclear Power Plants," which is draft form is designated as DS252. 


\section{Table 1 System Standards}

\begin{tabular}{|c|c|c|c|c|c|}
\hline \multirow{3}{*}{$\begin{array}{l}\text { Terminology } \\
\text { Overall Guide }\end{array}$} & \multicolumn{5}{|c|}{ IEC 60557 IEC lerminology in the nuclear reaclor lield / IEEE 100 Slandard Dictionary of Eleclical and Electronic Terms } \\
\hline & \multicolumn{5}{|c|}{ IAEA NS-R-1 Salely of Nuclear Power Plants: Design / $10 \mathrm{CFR} 50$ Domeslic Licensing of Production and Utilization Facililies } \\
\hline & \multicolumn{5}{|c|}{ IAEA DS-252. Instrumentation and Control Systems Impontant to Salely in Nuclear Power Plants } \\
\hline \multirow[t]{10}{*}{ Principles } & \multicolumn{5}{|c|}{ IEC 61226 Instrumentalion and control syslems inporlanl lor salely - Classification } \\
\hline & \multicolumn{5}{|c|}{ IEC. 51513 Instrumentialion and control for systems important to sateiv - General tequirements for syslems } \\
\hline & \multicolumn{5}{|c|}{ IEEE 603 Crileria Jor Safety Systems } \\
\hline & & \multicolumn{4}{|c|}{ Safely systems } \\
\hline & & \multicolumn{2}{|c|}{ Syslems Requirements } & \multicolumn{2}{|c|}{ Equipment Qualification } \\
\hline & & \begin{tabular}{|c|} 
IEC 60671 Periodic lests and \\
monitoring of the protection syslem \\
\end{tabular} & $\begin{array}{c}\text { TEEE } 338 \text { Periodic Surveillance Tesling } \\
\text { Of Sately Systems }\end{array}$ & $\begin{array}{l}\text { IEC } 60780 \text { Electrical equipment of the } \\
\text { sately syslem. Qualitication. }\end{array}$ & IEEE 323 Qualitying Class IE Equipment \\
\hline & & $\begin{array}{l}\text { IEC 60709 Separation within the } \\
\text { reaclor orolection system }\end{array}$ & \multirow{2}{*}{$\begin{array}{l}\text { IEEE } 384 \text { Independence of Class } 1 E \\
\text { Equipment and Circuits }\end{array}$} & $\begin{array}{c}\text { IEC } 60772 \text { Electrical penetration } \\
\text { assemblies } \\
\end{array}$ & $\begin{array}{c}\text { IEEE } 317 \text { Electric Penetration } \\
\text { Assembliss. }\end{array}$ \\
\hline & \multicolumn{2}{|c|}{ IEC 60639 Use of the protection system tor non-sately purposes } & & $\begin{array}{l}\text { IEEE } 334 \text { Oualifying Continuous Duty } \\
\text { Class } 1 \text { E Molors }\end{array}$ & \\
\hline & & IEC 60744 Salely logic assemblies & & $\begin{array}{l}\text { IEEE 3B3 Type Test of 1E } \\
\text { Cables, Splices, \& Conneclions } \\
\end{array}$ & \\
\hline & IEC 61497 ElE & trical interlocks & & \begin{tabular}{|c|} 
IEEE 535 Qualification of Class 1E Lead \\
Slorage Balleries \\
\end{tabular} & \\
\hline \multirow[t]{11}{*}{ Element Standards } & IEC 61225 Pequiremes & s for electrical supplies & & $\begin{array}{l}\text { IEEE } 572 \text { Ouallicalion of Class IE } \\
\text { Connection Assemblies }\end{array}$ & \\
\hline & PNW 45A-4\%9 Ma & agement of Ageing & $\begin{array}{c}\text { IEEE } 1205 \text { Assessing. Moniloring, and } \\
\text { Miligatiling Aging }\end{array}$ & $\begin{array}{l}\text { IEEE } 650 \text { Oualitication of IE Ballery } \\
\text { Charges and Inverters }\end{array}$ & \\
\hline & IEC 60987 Programmed digila & compulers important to satety & & $\begin{array}{l}\text { IEEE C37.82 Ouat of Switchgear } \\
\text { Assemblies for 1E Apps }\end{array}$ & \\
\hline & 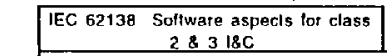 & \begin{tabular}{|c|} 
IEC 608Bo Software lor compulers in \\
sately_systems
\end{tabular} & \multirow{2}{*}{$\begin{array}{l}\text { IEEE 7-4.3.2 Digital Computers in } \\
\text { Safely Syslerns }\end{array}$} & \multirow[t]{2}{*}{\begin{tabular}{|c|} 
IEEE C37.105 Oual of 1 P Proleclive \\
Melays \& Auxlliaries
\end{tabular}} & \\
\hline & $\begin{array}{r}\text { IEC 60880-2 Sollware aspects of deten } \\
\text { software lools and of } \\
\end{array}$ & $\begin{array}{l}\text { e against common cause failures, use of } \\
\text { ore-developed software }\end{array}$ & & & \\
\hline & \multicolumn{2}{|c|}{ IEC 61500 Mulliplexed dala lransmission } & & \multicolumn{2}{|c|}{ IEEE C37.98 Seismic Testing ol Relays } \\
\hline & \multicolumn{2}{|c|}{ IEEE 933 Definition of Reliability Programs Plans } & & \multicolumn{2}{|c|}{ IEEE 833 Protection of Electric Equipment from Water Hazards } \\
\hline & \multicolumn{2}{|r|}{\begin{tabular}{|c|} 
IEEE 577 Peliability Analysis in the \\
Desigin and Operation of Sately Systems
\end{tabular}} & & \multirow{4}{*}{$\begin{array}{c}\text { IEC } 60980 \text { Recommended practices for } \\
\text { seismic qualificalion }\end{array}$} & \\
\hline & \multicolumn{2}{|r|}{\begin{tabular}{|c|} 
IEEE 336 Installation, Inspection, and \\
Testing of $18 \mathrm{CE}$ Equipment
\end{tabular}} & & & \\
\hline & \multicolumn{2}{|c|}{ IEEE B05 System Identilication } & & & \\
\hline & & $\begin{array}{c}\text { IEC 61940 A review of the application } \\
\text { of IEC } 60880\end{array}$ & $\begin{array}{l}\text { EEEE } 379 \text { Application of the Single } \\
\text { Failure cristerion }\end{array}$ & & $\begin{array}{l}\text { IEEE } 344 \text { Seismic Qualification of Class } \\
\text { IEEquiponent }\end{array}$ \\
\hline \multirow[t]{3}{*}{ Applicalion Guide } & \multicolumn{2}{|c|}{$\begin{array}{l}\text { IEC } 62082 \text { Framewo:k for developing standards on computer based systems and } \\
\text { software aspects }\end{array}$} & $\begin{array}{l}\text { IEEE 352 Principles of Reliability } \\
\text { Analysis for Salety Syslems } \\
\end{array}$ & & \\
\hline & IEC 61224 In silu re & ponse lime lor RTOs & & & \\
\hline & L. IEC 61888 Determination an & maintenance of trip selpoinls & & & \\
\hline \multirow[t]{2}{*}{ Techniques } & \multirow{2}{*}{\multicolumn{2}{|c|}{ 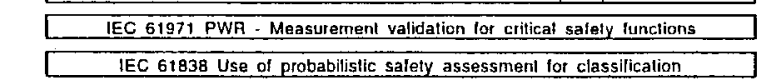 }} & & & \\
\hline & & & & & \\
\hline
\end{tabular}




\section{Table 2 Human Factors Engineering Standards}

Terminology

Overall Guide

Principles

Element Standards

Application Guide

Techniques
IEC 60557 IEC terminology in the nuclear reactor field / IEEE 100 Standard Dictionary of Electrical and Electronic Terms

IAEA 50-C-D Safely of Nuclear Power Plants: Design / 10 CFR 50 Domestic Licensing of Production and Utilization Facilities IEC 61226 Instrumentation and control systems important for safety - Classification

IAEA NS-252 Instrumentation and Control Systems Important to Salety in Nuclear Power Plants

IEC 61513 Instrumentation and control for systems important to safety - General requirements for systems

\begin{tabular}{|c|c|}
\hline \multicolumn{1}{|c|}{ Human Factors Engineering } \\
\hline Control Rooms & Specific HMI Systems \\
\hline
\end{tabular}

IEC 60964 Design of control

$$
\text { rooms }
$$

IEC 60960 Functional design criteria for SPDS

\section{IEC 61772 Main control room -}

visual display units (VDU)

IEC 60965 Supplementary control for remole shuldown

IEC 62247 Main Control Room

Design - A review of the

application of IEC 60964

1023 Application of Human Factors

Engineering to Systems, Equipment, and Facilities

IEEE 1289 Application of Human Factors Engineering in Computer Display Design

\begin{tabular}{c}
\hline $\begin{array}{c}\text { IEC } 61771 \text { Main control-room - } \\
\text { V\&V of desian }\end{array}$ \\
\hline $\begin{array}{c}\text { IEC } 61839 \text { Control rooms - } \\
\text { Functional analysis and } \\
\text { assianment }\end{array}$ \\
\hline
\end{tabular}

System Performance

IEEE 1082 Human Action Reliability Analysis 


\section{Table 3 IEC Specific Function Standards}

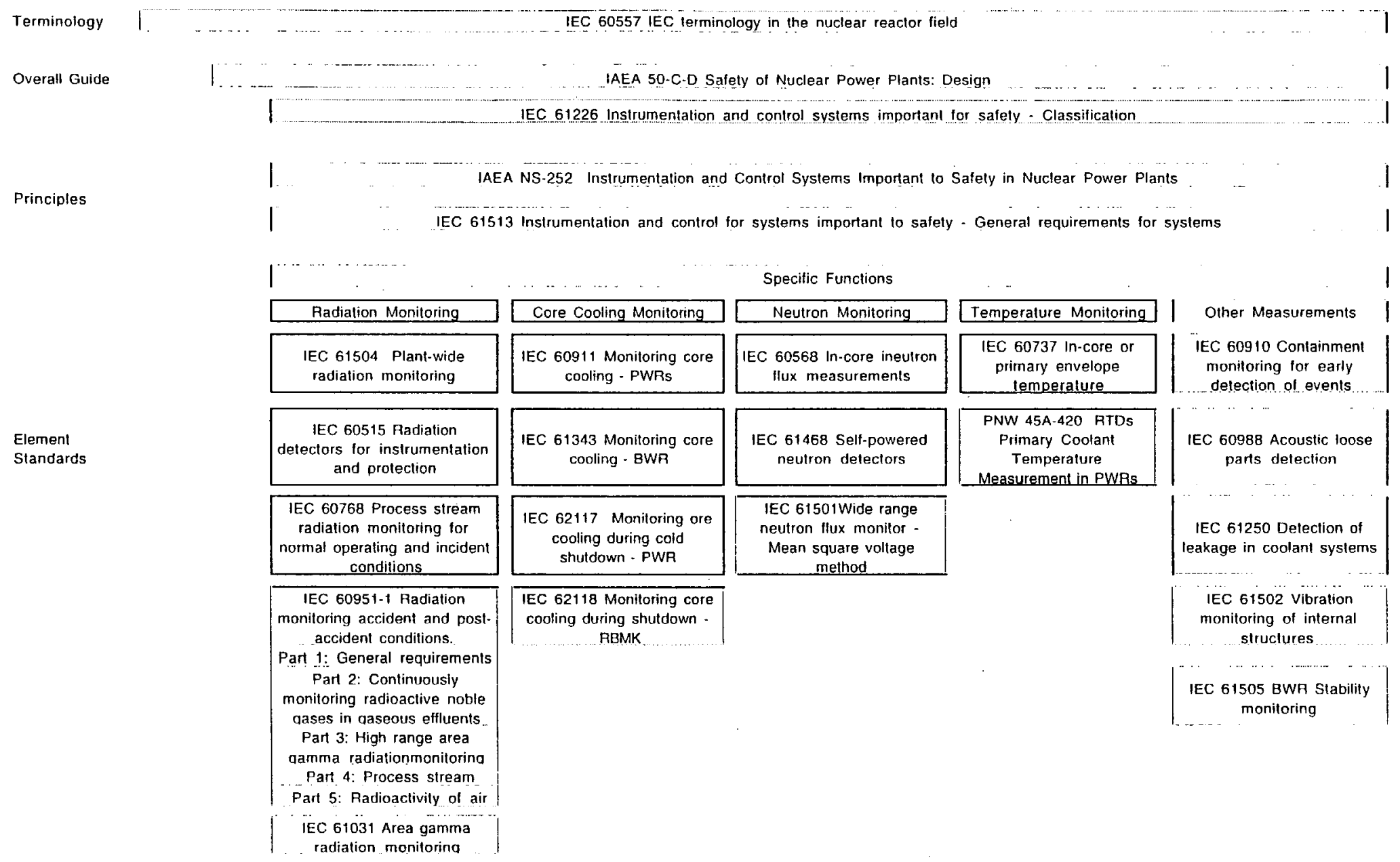




\section{Table 4 IEEE Specific Function Standards}

\begin{tabular}{|c|c|c|c|c|c|c|}
\hline Terminology & \multicolumn{6}{|c|}{ IEEE 100 Standard Dictionary of Electrical and Electronic Terms } \\
\hline Overall Guide & \multicolumn{6}{|c|}{10 CFR 50 Domestic Licensing of Production and Utilization Facilities } \\
\hline \multirow[t]{5}{*}{ Principles } & \multicolumn{6}{|c|}{ Systems Important to Safely } \\
\hline & \multicolumn{3}{|c|}{$\begin{array}{l}\text { IEEE } 603 \text { Criteria for Safety } \\
\text { Systems }\end{array}$} & & & \\
\hline & \multicolumn{6}{|c|}{ Specific Functions } \\
\hline & \multicolumn{2}{|c|}{ Electrical Systems } & $\begin{array}{c}\text { Cabling } \\
\text { Svstems }\end{array}$ & $\begin{array}{c}\text { Radiation } \\
\text { Monitoring } \\
\end{array}$ & Other Functions & Heal Tracing \\
\hline & $\begin{array}{c}\text { IEEE } 765 \\
\text { Preferred } \\
\text { Power Supply }\end{array}$ & $\begin{array}{c}\text { IEEE } 308 \text { Class } \\
1 E \text { Fower } \\
\text { Systems }\end{array}$ & $\begin{array}{l}\text { IEEE } 628 \\
\text { Raceway } \\
\text { Syslems }\end{array}$ & $\begin{array}{c}\text { IEEE N42.18 } \\
\text { Continuous } \\
\text { OnSite } \\
\text { Radiation } \\
\text { Monitoring } \\
\end{array}$ & $\begin{array}{l}\text { IEEE } 692 \\
\text { Criteria For } \\
\text { Security } \\
\text { Systems }\end{array}$ & \\
\hline \multirow[t]{5}{*}{ Element Standards } & & $\begin{array}{c}\text { IEEE } 387 \text { Diese! } \\
\text { Generators }\end{array}$ & $\begin{array}{c}\text { IEEE } 690 \text { Design } \\
\text { and Installation } \\
\text { of Cable } \\
\text { Systems } \\
\end{array}$ & $\begin{array}{c}\text { IEEE N320 } \\
\text { Emergency Pad } \\
\text { Monitoring }\end{array}$ & & \\
\hline & & $\begin{array}{c}\text { IEEE } 741 \\
\text { Protection of } \\
\text { Power Systems } \\
\text { and Equipment }\end{array}$ & $\begin{array}{l}\text { IEEE } 317 \\
\text { Electric } \\
\text { Penetration } \\
\text { Assemblies }\end{array}$ & & & \\
\hline & \multicolumn{2}{|c|}{$\begin{array}{c}\text { IEEE C37.2 Standard for Device Function Numbers and } \\
\text { Contact Designations }\end{array}$} & & & & \\
\hline & \multicolumn{2}{|c|}{$\begin{array}{c}\text { IEEE } 944 \text { Application and Testing of Uninterruptible } \\
\text { Power Supplies }\end{array}$} & & & & \\
\hline & \multicolumn{2}{|c|}{$\begin{array}{c}\text { IEEE 484 Design and Installation of Vented Lead Acid } \\
\text { Batleries }\end{array}$} & & & $\begin{array}{l}\text { IEEE } 1290 \text { MOV } \\
\text { Application. } \\
\text { Prolection. } \\
\text { Control, \& Test }\end{array}$ & $\begin{array}{c}\text { IEEE } 622 \text { Design and Installation of } \\
\text { Heat Tracing }\end{array}$ \\
\hline \multirow[t]{2}{*}{ Application Guide } & \multicolumn{2}{|c|}{$\begin{array}{c}\text { IEEE } 450 \text { Maintenance, Testing, and Replacement of } \\
\text { Vented Lead Acid Balleries } \\
\end{array}$} & & & & $\begin{array}{c}\text { IEEE 622A Installation of Electric } \\
\text { Pipe Heat Tracing }\end{array}$ \\
\hline & \multicolumn{2}{|c|}{$\begin{array}{c}\text { IEEE } 485 \text { Sizing Lead Acid Batteries for Stationary } \\
\text { Applications }\end{array}$} & & & & $\begin{array}{c}\text { IEEE 622B Testing and Startup for } \\
\text { Electric Heat Tracing }\end{array}$ \\
\hline
\end{tabular}

IEEE 1106 Maintenance, Testing, and Replacement of Nickel Cadmium Batteries IEEE 1050 1\&C Grounding 


\section{Terminology}

The IEEE and IEC take different approaches to terminology standards. The IEC attempts provide one definition of each term and coordinate each definition with other international bodies such as ISO and IAEA. The IEEE does not make a concerted attempt to uniquely define terminology, but simply catalogs each definition used in its standards with the expectation that writers will not develop a new definition where an old one will do. In any case, it is obvious that terminology should be coordinated to the extent practicable, but that some degree of inconsistency can be tolerated.

\section{Overall guidance}

Neither the IEEE nor IEC standards organizations provide the overall guidance for nuclear power systems. This function is reserved for national regulatory authorities. Thus the IEEE standards look to the requirements of the US Code of Federal Regulations, Section 10, Part 50, "Domestic Licensing of Production and Utilization Facilities," and in particular to Appendix A dealing with light water reactors (LWR). IEC standards, on the other hand, must account for the regulations of all member states. It is not practical for the working groups to be familiar with such a broad range of guidance, therefore the IAEA Safety Standard NS-R-1, "Safety of Nuclear Power Plants: Design" is used as the practical source of overall guidance. NS-R-1 is approved by the member states; thus it should represent guidance that is consistent with all member states' regulations. Nevertheless, there are differences in the nature of the NRC and IAEA guidance that cause unavoidable differences in detail. For example, the NRC regulations contain very specific requirements for LWRs while the IAEA requirements cover a broad range of reactor types.

The consistency between IAEA and NRC requirements is about as good as can be expected. Further improvement would help drive improved consistency between IEC and IEEE standards, but any change will happen very slowly. Thus IEC delegates from member states that base their nuclear regulations upon 10 CFR 50 have an important responsibility to ensure IEC standards are consistent with their national regulations. IEEE on the other hand could improve applicability of their standards to the international market by having a greater awareness of IAEA requirements and guidance. This might be achieved by broader international participation in IEEE nuclear standards subcommittees and working groups. Overlapping membership between IEEE and IEC committees should be encouraged.

\section{Principles}

The greatest overlap is in standards that provide basic design principles for nuclear power plant instrumentation and control systems. IAEA DS252 and IEEE 603 are comparable in purpose in that they layout fundamental strategies to assure high functional reliability of I\&C systems. DS252 has a broader scope, applying to systems important to safety, not just to the safety systems which are the scope of IEEE 603. DS252 also gives guidance on the application of the principles to specific systems, general principles for human factors engineering, and general principles for $I \& C$ system lifecycle. The preparation of DS252 included a specific effort to avoid conflict between it and IEEE 603.

IEC 61226 and 61513 support the guidance of DS252. IEC 61226 provides detailed guidance on a graded approach to system integrity, which is allowed by, but not described in detail by DS252. IEC 61513 provides a more detailed discussion of the I\&C system lifecycle. The preparers of DS252 also attempted to avoid conflicts with these two standards. 
Coordination among these four documents is key to establishing a common foundation for the design and acceptance of nuclear power plant $1 \& \mathrm{C}$ systems. It is recommended that updates of any one of these documents strive for consistency with the other three whenever possible. Where this is not possible, an effort should be made for the three organizations to agree upon common principles toward which future updates will move.

The greater breadth of IEC standards in this area offer IEEE an opportunity to endorse or adapt international practices for graded approach and design life cycles. These areas have, to some extent, been avoided by US standards activities because these topics are at the fringe of the regulatory spotlight in the US. The advent of software-based systems, however, has made life-cycle considerations more important. New approaches such as passive safety design and risk based regulation and new issues such as diversity requirements and alternative shutdown features are increasing the regulatory attention to systems that are important to safety, but not safety. Therefore, it may be time to more formally address these topics in US standards to support the next generation of reactor designs.

\section{Element standards and application guides}

In this analysis, element standards and application guides were classified into 4 groups: 1) system requirements, 2) equipment qualification, 3) human factors engineering, 4) specific $1 \& \mathrm{C}$ functions.

\section{System requirements}

The more complicated elements of integrity strategies espoused by both IEEE 603 and IAEA DS 252 are supported by standards covering a similar set of detailed topics. It is clear here that coordination is needed between IEEE 338 and IEC 6067) (surveillance test features); IEC 60709, IEC 60639 and IEEE 384 (independence), the IEC 60880 group and IEEE 7-4.3.2 (software), and IEEE 1205 (aging management) with the IEC againg management standard that is under development.

One of the past problems with coordination is that the current scope of IEC 60880 is very broad such that it is difficult to identify conflicts that needed to be addressed. The breadth of scope of IEC 60880 is being addressed by a new revision that is in preparation. The new revision refines the scope of the document in accordance with lessons learned from the application of the standard (IEC 69140) and from the development of a framework for standards on computer based systems (IEC 602082).

More perplexing are the areas where the coverage of the two sets of standards is different. IEC provides more guidance on specific types of safety systems such as interlocks and communications while IEEE provides more guidance on reliability analysis and assurance.

\section{Equipment qualification}

Both IEEE and IEC have high level standards addressing the fundamentals of environmental qualification. IEEE 323 and IEC 60780 cover environmental qualification. IEEE 384 and IEC 60980 cover seismic qualification. These may be the most commercially important standards of the set as they affect the marketability of a wide range of equipment. IEC recently updated IEC 60780 . At that time there was a sincere effort to check the update against IEEE 323 to identify and inform the IEC working group of any conflicts. A similar effort should be conducted wherever any of these standards are updated. 
IEEE has a series of standards dealing with the application of IEEE 323 to specific types of components. No parallel exists within the IEC standards set. IEC may wish to consider the need for a similar set of detailed standards.

\section{Human factors engineering}

The IEC and IEEE human factors engineering standards seem almost complementary. The IEEE standards cover design principles while the IEC standards cover specific applications of the design principles. There is a need to ensure that the guidance of these standards is consistent with each other and with the human factors engineering guidance of IAEA DS252.

\section{Standards for Specific I\&C Functions}

Both IEC and IEEE produce standards that impose requirements on specific I\&C functions. Remarkably, they mostly cover completely different sets of functions. The exception is radiation monitoring. In this area coordination between IEEE N42.18, IEEE N320, and the IEC 95] series of standards should be considered when any of these are updated.

In the other areas the standards are complementary. IEC covers many specific instrumentation and control functions, while IEEE has extensive standards on electrical power systems. It is not clear where the responsibility for nuclear power plant electrical power standards lay within IEC. IEC TC45 has the charter for nuclear power instrumentation, but it is not clear that it has the charter, or at the moment the proper membership, to cover electrical power systems. Other IEC committees, however, do not have the nuclear power specific background necessary and thus are not working in the area. IAEA has some guidance for electrical power systems, but this tends to be more at the principle level.

Ideally, the two groups of function standards could be used together. To do so would require resolution of any inconsistencies that may exist between these standards and the standards outlining principles for systems important to safety.

\section{Techniques}

There is very little overlap between technique standards of IEEE and IEC. In this area also the two groups of function standards could be used together.

\section{Conclusions and Recommendations}

Efforts to update existing IEEE and IEC standards should attempt to improve the harmony among the groups of standards. Groups of standards that deserve special attention towards coordination are listed in Table 5 below. Both IEEE and IEC have mechanisms for reporting issues and requisition interpretations of standards. These appear to be little used as a driver for the improvement of standards. More extensive use of these mechanisms to plan standard revisions and sharing of plans could facilitate the harmonization of the two sets of standards.

The highest priorities for harmonization are the principles group and the environmental qualification group. The principles group because harmony here will tend to drive harmonization of sub-tier standards. The environmental qualification groups because environmental and seismic qualification have a large effect on the marketability of equipment across national boundaries 


\section{Table 5 Summary of Related Standards}

\section{Principles}

IAEA DS-252 I\&C systems important to safety
IEC 61226 I\&C systems important for safety - classification
IEC 61513 I\&C for systems important to safety - General requirements for systems
IEEE 603 Criteria for Safety Systems

Environmental qualification

\begin{tabular}{|c|}
\hline IEC 60780 Electrical equipment of the safety system - qualification \\
IEEE 323 qualifying class le equipment \\
\hline IEC 60980 Recommended practices for seismic qualification \\
IEEE 344 Seismic qualification of class 1E equipment
\end{tabular}

Surveillance

IEC 60671 Periodic tests and monitoring of the protection system

IEEE 338 Periodic surveillance testing of safety systems

Independence

IEC 60709 Separation within the reactor protection system

IEC 60639 Use of the protection system for non-safety purposes

IEEE 384 Independence of Class $1 \mathrm{E}$ equipment and circuits

Software

IEC 60880 Software for computers in safety systems

IEC 60880-2 Software aspects of defense against CCF, use of software tools and of PDS

IEC 62138 Software aspects for class $2 \& 31 \& C$

IEEE 7-4.3.2 Digital computers in safety systems

Aging

IEEE 1205 Assessing, monitoring, and mitigating aging

PNW 45A-4 19 Management of aging

Radiation monitoring
IEC 6095] Radiation monitoring accident and post-accident conditions
IEEE N42.18 Continuous onsite radiation monitoring
IEEE N320 Emergency radiation monitoring

Future work will be done to understand the detailed changes needed to improve the harmony of the above standards.

For the coordination of new standards, it is hoped that tables 1 through 4 above will provide a ready reference for working groups to learn about existing work related to their new work items. 
Table6 summarizes the relationship between IEC and IEEE standards by topic areas. Outside of the above area there is little overlap between IEEE and IEC standards. In fact, the two sets of standards might be used in a complementary manner. Ideally, conflicts between these standards and the opposite organization's principles standards should be resolved to allow their use as normative standards in bot environments. Barring that, however, the IEEE standards can be considered as informative within the IEC context and vice versa.

\section{Table 6 IEC, IEEE, and IAEA Topic Coverage}

\begin{tabular}{|l|l|l|l|}
\cline { 2 - 4 } \multicolumn{1}{l|}{} & IEEE/SA & IEC & IAEA \\
\hline General Integrity Requirements & & & \\
\hline Surveillance & & & \\
\hline Independence & & & \\
\hline EQ - General & & & \\
\hline EQ - Specific & & & \\
\hline Software & & & \\
\hline Radiation Monitoring & & & \\
\hline Trip setpoints & & & \\
\hline HMl & & & \\
\hline HFE Principles & & \\
\hline Reliability Analysis & & \\
\hline Single Failure Criterion & & \\
\hline Electrical systems & & \\
\hline Security Systems & & \\
\hline Heat Tracing & & & \\
\hline Interlocks & & & \\
\hline Multiplexed Data Transmission & & & \\
\hline Measurement validation & & & \\
\hline Core Cooling Monitoring & & & \\
\hline Neutron Monitoring & & & \\
\hline Temperature Monitoring & & & \\
\hline Containment Monitoring & & & \\
\hline Stability Monitoring & & & \\
\hline Leakage Monitoring & & & \\
\hline Vibration / Lose Parts Monitoring & & & \\
\hline
\end{tabular}

\section{References}

Moore 1998, Software Engineering Standards, A User's Map, Moore, James W., IEEE Computer Society, Los Alamitos, CA, USA, 1998.

This work was performed under the auspices of the U.S. Department of Energy by the University of California, Lawrence Livermore National Laboratory under Contract No. W-7405-Eng-48. 